\title{
PERFORMANCE OF THE NILE TILAPIA WITH VARYING DAILY FEEDING AMOUNTS, USING A COMMERCIAL DIET
}

\author{
DESEMPENHO DA TILÁPIA DO NILO COM VARIAÇÃO DIÁRIA DA \\ ALIMENTAÇÃO, USANDO DIETAS COMERCIAIS
}

\author{
Glacio Souza ARAUJO'; ${ }^{1}$ Rafael Lustosa MACIEL ${ }^{2}$; Thales da Silva MOREIRA ${ }^{3}$; \\ Jefferson Pablo de Sousa SABOYA ${ }^{4}$; Renato Teixeira MOREIRA ${ }^{5}$; \\ José William Alves da SILVA ${ }^{6}$
}

1. Prof. Dr. do Instituto Federal de Educação, Ciência e Tecnologia do Ceará - IFCE, Campus Aracati, Ceará, Brasil. glacio@ifce.edu.br; 2. Prof. Dr. do Instituto Federal de Educação, Ciência e Tecnologia do Amazonas - IFAM, Campus Humaitá, Amazonas, Brasil; 3. Mestre em Engenharia de Pesca, Universidade Federal do Ceará, Fortaleza, Ceará, Brasil; 4. Prof. Dr. da Escola Estadual de Educação Profissional Marta Maria Giffoni de Sousa, Acaraú, Ceará, Brasil; 5. Prof. Dr. do Instituto Federal de Educação, Ciência e Tecnologia do Ceará - IFCE, Campus Morada Nova, Ceará, Brasil; 6. Prof. Dr. do Instituto Federal de Educação, Ciência e Tecnologia do Ceará - IFCE, Campus Aracati, Ceará, Brasil

\begin{abstract}
In order to evaluate the performance of Nile tilapia (Oreochromis niloticus), daily feeding amounts were varied in an experiment following a completely randomized design for 154 days and consisting of four treatments with three replications each, totaling 12 tanks with $3 \mathrm{~m}^{3}(3 \times 1 \times 1 \mathrm{~m})$ of area each at densities of 5 fish $\mathrm{m}^{-3}$ (initial) and 3 fish $\mathrm{m}^{-3}$ until the end of the experiment. Throughout the experimental period, the daily amount of feed was varied and delimited for each feeding time $(8 \mathrm{~h} 00,11 \mathrm{~h} 00,14 \mathrm{~h} 00$ and 17h00) as: 25;25; 25 and 25\% in daily treatment $1-\mathrm{T} 1 ; 20 ; 30 ; 30$ and 20\% in treatment $2-\mathrm{T} 2 ; 30 ; 20 ; 20$ and $30 \%$ in daily treatment $3-\mathrm{T} 3$; and 20;30; 20 and 30\% in treatment 4 - T4. Feed was offered six days a week, with extruded isocaloric $(1,412 \mathrm{KJ})$ and isoproteic $(32 \%$ crude protein) diets from 2 to $4 \mathrm{~mm}$. Every two weeks, a sample containing $30 \%$ of stocked individuals was collected in each replication to monitor fish growth. Nile tilapia (O. niloticus) fed in daily amounts of $20 ; 30 ; 20$ and $30 \%$ showed a better growth performance in the final of experiment, mainly on biomass, final average weight and feed conversion.
\end{abstract}

KEYWORDS: Aquaculture. Cultivation. Growth. Oreochromis niloticus. Production.

\section{INTRODUCTION}

Aquaculture is the cultivation of aquatic organisms with the intervention of man in the breeding process with the aim of increasing production, in operations such as reproduction, stocking, feeding, and protection against predators, among others (FAO, 1990).

Brazil has the most ichthyic fauna and the largest hydrographic basins in the world, such as the Amazon, Prata, and São Francisco basins. Furthermore, the country possesses a large territorial volume, encompassing $2 / 3$ of the tropical region, as well as 5,000,000 hectares of dammed water, which constitutes important characteristics for the development of aquaculture. In recent years, aquaculture in Brazil has been growing at significant rates and, therefore, knowledge of the potentialities that can be exploited for advancement is fundamental for development, as well as identifying the primary problems faced by the aquaculture sector (OSTRENSKY; BORGHETTI; SOTO, 2008).

The Nile tilapia, Oreochromis niloticus, stands out in fish farming in the interior waters of regions with hot climates, both in ground tanks and cages, or net-tanks, the latter being greatly used in large reservoirs (ARAUJO et al., 2010). Characteristics such as high productivity, hardiness, a large capacity for adaptation, and fillets that are highly accepted in the consumer market are qualities that justify this prominence (MEURER et al., 2000).

A growing demand for animal protein is also encouraging the culture of others species from the Oreochromis genus, such as $O$. mossanbicus, $O$. aureus and $O$. urolepsis, as well as certain hybrid varieties. Several practices and production systems are currently being tested to optimize tilapia growth (WATANABE et al., 2002).

Feeding is one of the most important aspects in the cultivation of aquatic organisms, as the costs can become rather high depending on the feeding strategy adopted (MARTINEZ-CORDOVA et al., 1998).

This study aimed to evaluate the influence of different feed amounts offered throughout the day on the growth performance of Nile tilapia (Oreochromis niloticus). 
Performance of the...

\section{MATERIAL AND METHODS}

\section{Experimental design}

The experiment was conducted at the Fish Culture Station Prof. Raimundo Saraiva da Costa of the Fisheries Department of Ceará Federal University for a period of 154 days of cultivation.

A total of 180 sexually reverted juvenile tilapia were used in this experiment, with initial average weight and length of $62.93 \pm 18.58 \mathrm{~g}$ and $15.02 \pm 0.35 \mathrm{~cm}$, respectively.

The experiment followed a completely randomized design and consisted of four treatments and three replications using $3 \mathrm{~m}^{3}(3 \mathrm{mx} 1 \mathrm{mx} 1 \mathrm{~m})$ tanks at an initial stocking density of 5 fish $\mathrm{m}^{-3}$ until reaching average weight and length of $200.43 \pm 10.08$ $\mathrm{g}$ and $22.32 \pm 0.73 \mathrm{~cm}$, respectively (first stage of the experiment). After this period until the end of the experiment, a stocking density of 3 fish $\mathrm{m}^{-3}$ was used.

Feed was offered in four meals a day at $8 \mathrm{~h} 00,11 \mathrm{~h} 00,14 \mathrm{~h} 00$ and $17 \mathrm{~h} 00$, six days a week, with an extruded isocaloric $(1412 \mathrm{KJ})$ and isoproteic (32\% crude protein) 2- to $4-\mathrm{mm}$ pelleted ration. Initial feeding rate was $5 \%$ of biomass, and was gradually reduced to $2 \%$ by the end of the experiment. The fish were fed six days a week due to technical unviability of feeding during the seven days of the week, but following the same diet in all treatments, with feed restriction once a week,
ARAUJO, G. S. et al.

because according to Gurney et al. (2003), when food is again available, many organisms exhibit compensatory responses that induce into a faster growth when compared to individuals exposed to continuous and high food availability.

Compensatory growth can be divided into different categories according to the extent to which it occurs, which may be partial, complete or, a rarer phenomenon, called over compensation (ALI; NICIEZA; WOOTTON, 2003). The correct feeding frequency and the appropriate use of food restriction may allow the use of smaller amounts of ration and manpower directed for feeding, which leads to a decrease in cultivations expenditure (SOUZA; URBINATI; OLIVEIRA, 1997; SOARES et al., 2007).

Total daily feeding was divided in four different treatment amounts, as follows: $25 \%, 25 \%$, $25 \%$ and $25 \%$ in treatment 1 (T1); 20\%, 30\%, 30\% and $20 \%$ in treatment 2 (T2); 30\%, 20\%, 20\% and $30 \%$ treatment in 3 (T3); and 20\%, 30\%, 20\% and $30 \%$ in treatment 4 (T4) (Table 1). This methodology was used to obtain a higher survival, final weight gain of the animals and consequent production, with the same amount of daily ration in all treatments $(100 \%)$, but varying the amounts in each alimentary tract by virtue of the time of day, thus optimizing the supply of food in the defined periods.

Table 1. Description of the different treatments used in this experiment.

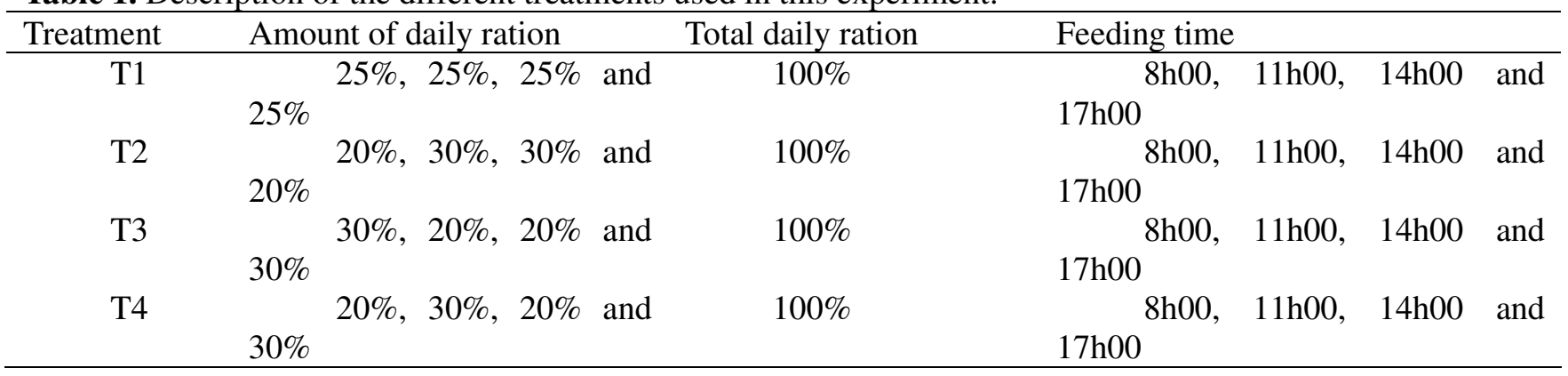

A sample from each treatment containing $30 \%$ of individuals was collected every two weeks using a hand net, and average weights and lengths were obtained. Dead individuals were removed and counted to assess survival; $78 \mathrm{mg} \mathrm{L}^{-1}$ eugenol was used in order to minimize animal stress during handling.

\section{Analyses of growth parameters}

Growth parameters survival rate (S), final biomass (B), average weight and length, mean daily weight gain (MDWG), feed efficiency (FE) and feed conversion rate (FCR) were determined at the end of the experiment to evaluate fish performance, and were calculated as follows, according to Carneiro, Cyrino and Castagnolli (1999):

Survival rate $(S)=100 \times$ (final amount of fish) / (initial amount of fish);

Final biomass $(\mathrm{B})=($ final amount of fish $\mathrm{x}$ (final weight of fish - initial weight of fish)) / 1000;

Mean daily weight gain $(\mathrm{MDWG})=($ final weight of fish - initial weight of fish) / days of the experiment;

Feed efficiency $(\mathrm{FE})=100 \times$ (final weight of fish - initial weight of fish) / feed consumed; 
Performance of the...

Feed conversion rate $(\mathrm{FCR})=$ feed consumed / biomass.

\section{Analyses of the Viscerosomatic (GSI\%), Hepatosomatic (HSI\%) and Visceral Fat-Somatic Indexes (VFSI\%)}

Fillet, head and carcass yields were also determined, and viscera, liver and visceral fat weights were used to obtain the viscerosomatic (GSI\%), hepatosomatic (HSI\%) and visceral fatsomatic indexes (VFSI\%), respectively, were calculated as follows, according to $\mathrm{Ng}$ and Wang (2011):

Viscerosomatic index $(\mathrm{GSI} \%)=100 \mathrm{x}$ viscera weight / whole body weight;

Hepatosomatic index $(\mathrm{HSI} \%)=100 \times$ liver weight / whole body weight;

Visceral fat-somatic indexes $($ VFSI $\%)=100$ $\mathrm{x}$ visceral fat weight / whole body weight.

\section{Elementary chemical analysis}

At the end of the experiment, three fish per treatment were used to perform the elemental chemical analysis of the fillets by determining moisture, crude protein, lipid and ash contents. These tests were performed according to methods described by the Association of Official Analytical Chemists - AOAC (1995). Moisture content was determined by weighing two grams of fillets in preweighed porcelain crucibles placed in an oven at $105^{\circ} \mathrm{C}$ for $24 \mathrm{~h}$ and then kept in desiccators until reaching room temperature. Moisture content was obtained by the difference between the initial and final weight of the samples.

Ash content was obtained by weighing two grams of each sample in pre-weighed porcelain crucibles and kept in a muffle furnace at 550 - 600 ${ }^{\circ} \mathrm{C}$ for four hours. The crucibles containing the completely incinerated organic material were then kept in a desiccator until reaching room temperature and weighed. Ash content was the difference between the initial and residual weights, expressed as a percentage.
ARAUJO, G. S. et al.

Crude protein determination was performed by the Kjeldhall method, using digestion with sulfuric acid $\left(\mathrm{H}_{2} \mathrm{SO}_{4}\right)$, distillation with sodium hydroxide $(\mathrm{NaOH})$ and titration with $0.1 \mathrm{~N}$ sulfuric acid, considering 6.25 as the conversion factor from total nitrogen to crude protein.

Total lipid content in samples containing two grams of fillet were determined by keeping them in packs of filter paper and placing them in a Soxhlet extraction unit containing approximately $100 \mathrm{~mL}$ of acetone. After an eight-hour extraction period, the solvent was evaporated in an oven at 105 ${ }^{\circ} \mathrm{C}$ and the resulting material was weighed. The lipid content was based on the ratio between the weight of extracted lipids and the initial weight of the sample, and was expressed as a percentage.

\section{Physical-chemical parameters of the water and statistical analysis}

Temperature $\left({ }^{\circ} \mathrm{C}\right)$ and water dissolved oxygen concentration $\left(\mathrm{mg} \mathrm{L}^{-1}\right)$ were measured using a YSI 55 oximeter by Bernauer Aquacultura, and a Q-400HM portable $\mathrm{pH}$ meter was used to measure $\mathrm{pH}$. All parameters were assessed weekly.

In general, dissolved oxygen concentration values were higher at $14 \mathrm{~h} 00$, due to intense photosynthetic activity (Table 2 ).

During the entire experiment, $\mathrm{pH}$ values were near neutrality and slightly more elevated at $11 \mathrm{~h} 00$ and $14 \mathrm{~h} 00$, while water temperature remained between 27.58 and $31.47{ }^{\circ} \mathrm{C}$, with an increase of around three degrees between first $(8 \mathrm{~h})$ and 17 hours.

Tran-Duy et al. (2008) found the effects of two dissolved oxygen concentrations (3.0 and 5.6 $\mathrm{mg} \mathrm{L}^{-1}$ ) on the body weight and growth of 21 and $147 \mathrm{~g}$ average weight Nile tilapias (O. niloticus). They observed a significant increase in average weight of fish submitted to the higher dissolved oxygen concentration, as well as greater growth of the $21 \mathrm{~g}$ animals when compared to those cultivated in a lower oxygen concentration.

Table 2. Dissolved oxygen concentration, $\mathrm{pH}$ and average temperature values of water during the daily feeding period.

\begin{tabular}{|c|c|c|c|c|c|c|c|c|c|c|c|c|}
\hline \multirow[t]{2}{*}{ Treat. } & \multicolumn{4}{|c|}{$\begin{array}{l}\text { Dissolved oxygen } \\
\left(\mathrm{mg} \mathrm{L}^{-1}\right)\end{array}$} & \multicolumn{4}{|l|}{$\mathrm{Ph}$} & \multicolumn{4}{|c|}{$\begin{array}{l}\text { Temperature } \\
\left({ }^{\circ} \mathrm{C}\right)\end{array}$} \\
\hline & $8 \mathrm{~h}$ & $11 \mathrm{~h}$ & $14 \mathrm{~h}$ & $17 \mathrm{~h}$ & $8 \mathrm{~h}$ & $11 \mathrm{~h}$ & $14 \mathrm{~h}$ & $17 \mathrm{~h}$ & $8 \mathrm{~h}$ & $11 \mathrm{~h}$ & $14 \mathrm{~h}$ & $17 \mathrm{~h}$ \\
\hline T 1 & 4.52 & 5.23 & 5.81 & 4.97 & 6.40 & 6.75 & 7.23 & 6.37 & 27.58 & 29.28 & 30.68 & 30.80 \\
\hline Т 2 & 4.36 & 4.95 & 5.51 & 4.35 & 6.55 & 7.03 & 6.88 & 6.15 & 28.18 & 29.61 & 31.24 & 31.47 \\
\hline Т 3 & 4.30 & 4.96 & 5.48 & 4.28 & 6.70 & 7.07 & 7.02 & 5.93 & 27.63 & 29.39 & 30.84 & 31.03 \\
\hline T 4 & 4.48 & 4.83 & 5.10 & 4.28 & 6.47 & 6.90 & 6.73 & 6.17 & 27.90 & 29.58 & 31.09 & 31.42 \\
\hline
\end{tabular}


According to Moreira et al. (2011), the values recorded for the water quality parameters (dissolved oxygen, $\mathrm{pH}$ and temperature) remained within the levels considered adequate for the cultivation of tilapia.

The results obtained were similar to those shown by Lima et al. (2008) in which water quality in an integrated cultivation system was evaluated, involving fish farming and aquaculture, with a stock density of 10, 20, and 30 tilapia per cubic meter. The tested densities did not negatively alter the water quality. The authors thus concluded that the possibility of integrating fish farming with agriculture exists, maximizing the use of hydric resources.

To check whether the different treatments influenced fish performance, the growth and physical-chemical parameters values were submitted to a one-way analysis of variance (ANOVA); whenever significant differences were observed, a means comparison test was applied. All statistic tests were done using BioEstat software version 4.0.

\section{RESULTS AND DISCUSSION}

\section{Fish performance in the first stage of the experiment}

Adequate feed frequency stimulates fish to look for food at predetermined times and contributes to improve feed conversion, increases weight gain, reduces ration waste and production costs, provides better quality of cultivation water, as well as to provide a greater opportunity to observe the health status of the fish by means of alterations in the food activity (SANCHES; HAYASHI, 2001; CARNEIRO; MIKOS, 2005; SANTOS et al., 2014).

The amount of ration supplied to the fish and the feeding frequency can influence the productivity at the end of the cultivation and consequently the economic gain of the business. The level of feeding below the physiological needs can result in low productive performance and increase in cultivation time, influencing the economic return of the activity (MEURER et al., 2005). Excess feed may lead to food waste, increasing production costs and poor water quality (SANTOS et al., 2013) and, consequently, impair zootechnical performance, increase the incidence of diseases and mortality, and cause eutrophication of the aquatic environment (MEURER et al., 2005; MEURER et al., 2007; SALARO et al., 2008).

The amount of food supplied or the frequency with which it is administered may influence its utilization, once the feed is placed directly in the water. The portion of unconsumed feed will either be diluted or leached, causing increased feed conversion rates and reduced water quality (LOURES et al., 2001).

Yao, Umino and Nakagawa (1994), analyzing the effects of feeding frequency on Plecoglossus altivelis (ayu), reported that the fish fed four times a day, as occurred in the respective experiment, had a lower level of triglycerides than those fed only twice a day.

For tilapia, at different stages of cultivation, the findings diverge within twice-daily intervals (GUERRERO, 1975), two to four times a day (POPMA; GREEN, 1990), four times a day (PHELPS et al., 1995) and six to eight times a day (CRUZ; MAIR, 1994).

For eels (Anguilla anguilla), Seymour (1989) concluded that there was no greater consumption that justified feeding more than four times a day, as occurred in this experiment.

At the end of the first phase of the experiment, the greatest survival rates were obtained in the treatments in which we used amounts of $30 \%$, $20 \%, 20 \%$ and $30 \%$ (T3); and amounts of $20 \%$, $30 \%, 20 \%$ and $30 \%$ (treatment T4) of the daily feeding, both with values of $100.00 \pm 0.00 \%$, significantly different from the rest of the treatments $(\mathrm{p}<0.05)$, but not from each other. Under these conditions, the lowest survival rate found was in treatment $\mathrm{T} 2$, in which the fish were fed daily with amounts of 20\%, 30\%, 30\% and 20\% $(90.00 \pm 4.71 \%)$ of the feeding (Table 3). These values are relatively found in existing commercial fisheries in the state of Ceará.

Table 3. Survival (S), biomass (B), final weight (W), final length (L), daily weight gain (DWG) and feed conversion rate (FCR) of fishes in all treatments at the end of the first stage of the experiment.

\begin{tabular}{lllllll}
\hline Treat. & $\begin{array}{l}\mathrm{S} \\
(\%)\end{array}$ & $\begin{array}{l}\mathrm{B} \\
(\mathrm{kg})\end{array}$ & $\begin{array}{l}\mathrm{W} \\
(\mathrm{kg})\end{array}$ & $\begin{array}{l}\mathrm{L} \\
(\mathrm{cm})\end{array}$ & $\begin{array}{l}\text { DWG } \\
(\mathrm{g} \mathrm{day})\end{array}$ & FCR \\
\hline T 1 & $95.56 \pm 3.85^{\mathrm{a}}$ & $2.11 \pm 0.24^{\mathrm{a}}$ & $0.21 \pm 0.02^{\mathrm{a}}$ & $21.61 \pm 0.58^{\mathrm{a}}$ & $2.11 \pm 0.26^{\mathrm{a}}$ & $2.23 \pm 0.04^{\mathrm{a}}$ \\
T 2 & $90.00 \pm 4.71^{\mathrm{a}}$ & $1.49 \pm 0.15^{\mathrm{b}}$ & $0.18 \pm 0.02^{\mathrm{a}}$ & $19.72 \pm 0.11^{\mathrm{b}}$ & $1.59 \pm 0.25^{\mathrm{a}}$ & $2.29 \pm 0.03^{\mathrm{a}}$ \\
T 3 & $100.00 \pm 0.00^{\mathrm{b}}$ & $2.12 \pm 0.20^{\mathrm{a}}$ & $0.21 \pm 0.01^{\mathrm{a}}$ & $21.89 \pm 0.19^{\mathrm{a}}$ & $2.02 \pm 0.19^{\mathrm{a}}$ & $2.42 \pm 0.03^{\mathrm{b}}$ \\
T 4 & $100.00 \pm 0.00^{\mathrm{b}}$ & $2.12 \pm 0.40^{\mathrm{a}}$ & $0.20 \pm 0.01^{\mathrm{a}}$ & $21.19 \pm 0.92^{\mathrm{a}}$ & $2.02 \pm 0.38^{\mathrm{a}}$ & $2.40 \pm 0.04^{\mathrm{b}}$ \\
\hline
\end{tabular}

Values are expressed as averages and standards errors. Equal letters indicate absence of significant differences between treatments. 
The greatest biomass values were obtained in treatments T3, T4 and T1, which were significantly different from treatment $\mathrm{T} 2(\mathrm{p}<0.05)$, but not significantly different from each other. In treatment $\mathrm{T} 2$, the lowest biomass value was observed $(1.49 \pm 0.15 \mathrm{~kg})$. This same situation was confirmed when the average final length of the fish was analyzed.

The average final weight and mean daily weight gain of the fish at the end of the first phase were also higher in treatments $\mathrm{T} 3, \mathrm{~T} 1$, and $\mathrm{T} 4$, but significant differences from $\mathrm{T} 2$, nor within the group of three treatments, were not presented ( $>0.05)$.

Finally, the best feed conversion rates were obtained in the treatments in which the following amounts were used: $25 \%, 25 \%, 25 \%$ and $25 \%$ (T1) and $20 \%, 30 \%, 30 \%$ and $20 \%$ (T2) of the daily feeding, with values of $2.23 \pm 0.04$ and $2.29 \pm 0.03$, respectively, which were significantly different from the rest of the treatments $(p<0.05)$, but not from each other (Table 3).

Gonçalves et al. (2014) cultivated 84 piapara (Leporinus elongatus) juveniles in three treatments (control group: animals fed every day; FDS group: fish that did not receive food on the weekends, that is, fed five days and had food restriction in two days and group Res 21: animals submitted to food restriction in the first 21 days of experiment, followed by feedback until the end of the experiment), for a period of 78 days, until apparent satiety in two meals daily (10 and 16 hours), using commercial extruded ration containing $32 \%$ of crude protein and 4 to $6 \mathrm{~mm}$ pellets and observed that the animals that suffered food restriction in the initial 21 days obtained higher weight gain and higher food consumption in both feedback periods, which demonstrates compensatory weight gain , mainly using hyperphagia as compensatory response mechanism. There were no differences for weight gain and food consumption between the control group and the animals of the FDS group, which, in turn, resulted in a saving of $15.32 \%$ in consumption in relation to the control group.

Santos et al. (2015) evaluated the performance of Nile tilapia fingerlings (Oreochromis niloticus) submitted to different feeding levels $(6,9$ and $12 \%$ of body weight per day) and feeding frequencies (4 and 6 times a day) for a period of 35 days fed with ration bran containing $48 \%$ crude protein and observed that the feeding frequency did not influence the productive performance of the fish and that the best performance of the fingerlings was observed with the feeding level of $9 \%$ of live weight per day, in four daily meals.

Loures et al. (2001) evaluated the food management of Nile tilapia fingerlings, $O$. niloticus, fed with commercial ration, offered four times a day, with different levels of vitamin $\mathrm{C}$ and observed that the degree of repletion of the stomach (GR) is influenced by air temperature, time of the day, water temperature, $\mathrm{pH}$, phytoplankton biovolume and collection number. The highest values for GR were obtained during the hottest times of the day, demonstrating that food consumption occurs, preferably, at higher temperatures, which coincides with the period of greatest luminosity, characterizing the species as diurnal and that the type of preferential food was the artificial (commercial ration).

Guo et al. (2011) replaced soybean meal (SBM) with sesame meal (SM) in a diet for Nile tilapia (O. niloticus) fry with an average initial weight of $8.74 \pm 0.12 \mathrm{~g}$, during a period of 8 weeks. Seven different diets were utilized $\left(33 \mathrm{~g} \mathrm{~kg}^{-1}\right.$ of protein and $19.2 \mathrm{MJ} \mathrm{kg}^{-1}$ of the diet), with a substitution of levels of $0 ; 8 ; 16 ; 24 ; 32 ; 40$ and $48 \%$ of SM for SBM. The authors verified that the survival rate was not significantly different between the diets, but factors including the final average weight, weight gain (GP), specific growth and feed conversion rates in the treatment which used $16 \%$ SM were similar to the results obtained in the control treatment. This indicated that SM can be utilized in Nile tilapia fry in this concentration without causing negative effects to the animals in relation to productive performance.

Similarly, Navarro et al. (2010) did not observe statistically significant differences with relation to the survival rate of reverted post-larval tilapia with supplementation of an isoproteic (36\% of $\mathrm{PB}$ ) and isocaloric (3600 kcal of ED. $\mathrm{kg}^{-1}$ ) ration with different concentrations of monophasic vitamin E $\left(0 ; 50 ; 100 ; 150\right.$ and $\left.200 \mathrm{mg} . \mathrm{kg}^{-1}\right)$. The authors also verified that statistically significant differences did not occur with relation to final weight, daily weight gain, proteinic efficiency and fish survival rates.

In general, at the end of the first phase of the experiment, the results showed better values of survival, final biomass, final average weight, final length, and daily weight gain for the treatment in which the fish were fed with amounts of $30 \%, 20 \%$, $20 \%$ and $30 \%$ (T3) of the daily feeding (Table 3 ). The fish fed during the first $(800 \mathrm{~h})$ and last $(1700 \mathrm{~h})$ periods of the day with a larger quantity of ration exhibited greater efficiency, probably because of a greater need for food due to the previous night and 
the need for greater consumption at the end of the afternoon in this phase of the cultivation of these animals.

\section{Fish performance in the end of the experiment}

At the end of the second phase of the experiment (154 days), the greatest survival rate was found for the treatment which utilized amounts of $20 \%, 30 \%, 30 \%$ and $20 \%$ of the daily feeding (T2) $(100.00 \pm 0.00 \%)$, significantly different from the treatment 1 (T1) $(\mathrm{p}<0.05)$, which presented the smallest value in relation to this parameter $(85.18 \pm 6.42 \%)$, but differences between the rest of the treatments (T3 and T4) did not occur (Table 4).

Table 4. Survival (S), biomass (B), final weight (W), final length (L), daily weight gain (DWG) and feed conversion ratio (FCR) of fishes in all treatments at the end of 154 days of the experiment.

\begin{tabular}{lllllll}
\hline Treat. & $\begin{array}{l}\mathrm{S} \\
(\%)\end{array}$ & $\begin{array}{l}\mathrm{B} \\
(\mathrm{kg})\end{array}$ & $\begin{array}{l}\mathrm{W} \\
(\mathrm{kg})\end{array}$ & $\begin{array}{l}\mathrm{L} \\
(\mathrm{cm})\end{array}$ & $\begin{array}{l}\text { DWG } \\
(\mathrm{g} \mathrm{day})\end{array}$ & FCR \\
\hline T 1 & $85.18 \pm 6.42^{\mathrm{a}}$ & $1.61 \pm 0.31^{\mathrm{a}}$ & $0.42 \pm 0.03^{\mathrm{a}}$ & $28.56 \pm 1.44^{\mathrm{a}}$ & $4.99 \pm 0.56^{\mathrm{a}}$ & $2.56 \pm 0.09^{\mathrm{a}}$ \\
T 2 & $100.00 \pm 0.00^{\mathrm{b}}$ & $2.36 \pm 0.23^{\mathrm{b}}$ & $0.43 \pm 0.04^{\mathrm{a}}$ & $28.14 \pm 1.22^{\mathrm{a}}$ & $5.25 \pm 0.48^{\mathrm{a}}$ & $2.15 \pm 0.06^{\mathrm{b}}$ \\
T 3 & $92.59 \pm 6.42^{\mathrm{ab}}$ & $2.35 \pm 0.14^{\mathrm{b}}$ & $0.44 \pm 0.03^{\mathrm{a}}$ & $29,33 \pm 0.29^{\mathrm{a}}$ & $5.80 \pm 0.15^{\mathrm{a}}$ & $2.06 \pm 0.09^{\mathrm{bc}}$ \\
T 4 & $96.30 \pm 2.42^{\mathrm{ab}}$ & $2.67 \pm 0.36^{\mathrm{b}}$ & $0.51 \pm 0.03^{\mathrm{b}}$ & $28.70 \pm 0.78^{\mathrm{a}}$ & $6.06 \pm 0.58^{\mathrm{a}}$ & $1.88 \pm 0.08^{\mathrm{c}}$ \\
\hline
\end{tabular}

Values are expressed as averages and standards errors. Equal letters indicate absence of significant differences between treatments.

The greatest biomass was obtained in treatment $\mathrm{T} 4(2.67 \pm 0.36 \mathrm{~kg})$, significantly different from treatment $1(\mathrm{~T} 1)(\mathrm{p}<0.05)$, but differences did not occur between the rest of the treatments. Additionally, the greatest value for average final weight $(0.51 \pm 0.09 \mathrm{~kg})$ was obtained in treatment $\mathrm{T} 4$, statistically different from the rest.

These results contributed to the smallest feed conversion rate found in treatment $\mathrm{T} 4$ (1.88 \pm 0.08$)$, statistically similar to treatment $\mathrm{T} 3$, but different from the rest of the treatments (T1 and T2). It is worth pointing out that the greater feed conversion rate was obtained in the treatment in which amounts of $25 \%, 25 \%, 25 \%$ and $25 \%$ of the daily feeding were utilized (T1), with a value of $2.56 \pm 0.09$ (Table 4).

With regards to Table 4, statistically significant differences were not found in relation to average final length and mean daily weight gain of the fish in all of the treatments.

As such, at the end of the experiment, the Nile tilapia (O. niloticus) fed with amounts of $20 \%$, $30 \%, 20 \%$ and $30 \%$ (treatment $\mathrm{T} 4$ ) of the daily quantity presented the best results, verified by the survival rate, biomass, average final weight and feed conversion rate.

Michelato et al. (2016) studied lysine exigency in the growth and yield of Nile tilapia $(O$. niloticus) fillets. 600 fish were used, with an average weight of $274.9 \pm 3.3 \mathrm{~g}$, distributed in fifteen $1.2 \mathrm{~m}^{3}$ cages, with 5 treatments and three replications, comprising $(11.1 ; 12.5 ; 13.9 ; 15.1$ and $16.4 \mathrm{~g}$ of lysine $\mathrm{kg}^{-1}$ ). The authors verified that the fish fed with $15.1 \mathrm{~g}$ of lysine $\mathrm{kg}^{-1}$ presented the best average final weight and daily weight gain.

Reda et al. (2016) evaluated the use of a mixture of fomic acid, propionic acid, and calcium propionate and its salts in comparison with oxytetracycline, in apparently healthy Nile tilapia (O. niloticus) fry, with an average weight of $28.8 \pm 0.14 \mathrm{~g}$, for a period of 60 days. The authors observed that the fish fed with the diet containing formic acid and a mixture of propionic acid/salt in 2 g. $\mathrm{kg}^{-1}$ presented significant improvements in total body weight, weight gain, specific growth and feed conversion rates, in comparison with the other treatments.

Freato et al. (2012) submitted Nile tilapia (O. niloticus) juveniles to four feeding programs consisting of different levels of crude protein (PB) in different phases of cultivation and verified that the diets containing 36\%, 32\%, and $28 \% \mathrm{~PB}$, respectively, promoted greater weight gain and final biomass. The same authors also observed that levels less than $36 \%$ PB in tilapia with weights between 60 and $170 \mathrm{~g}$, as well as levels below $32 \%$ PB in tilapia with weights between 170 and $700 \mathrm{~g}$ negatively affected the performance of the fish.

The absolute results in weight gain, survival rate, and feed conversion rate, which determine the cost of production and consequently the economic viability of pisciculture projects, are directly dependent on the quality of the cultivation environment (SAMPAIO; BRAGA, 2005).

In general, at the end of the second phase of the experiment (154 days), the best results with regards to final biomass, average final weight, mean daily weight gain, and feed conversion factor were found in fish fed with amounts of $20 \%, 30 \%, 20 \%$ and $30 \%$ of the daily feeding (Table 4). The fish fed in the second period of the day (11:00h), received a greater quantity of ration, in water with a higher temperature and a greater content of dissolved oxygen, in relation to the first feeding treatment at 
Performance of the...

8:00h in the morning (Table 2); these factors, in addition to a greater need for food at the end of the afternoon in this phase of the cultivation of these animals, probably justify the obtained results.

We have observed that the worst results occur when the traditional feeding methods (2525\%, $25 \%, 25 \%$ and $25 \%$ of the daily feeding - T1) are utilized, which demonstrates the necessity of modifiying the daily feeding quantity in order to obtain the best production performance of the animals.

\section{Analyses of the Viscerosomatic (GSI\%), Hepatosomatic (HSI\%) and Visceral Fat-Somatic Indexes (VFSI\%)}

ARAUJO, G. S. et al.

Table 5 shows the yield results of tilapia fillet, head, and carcass, viscerosomatic, hepatosomatic, and visceral fat-somatic indexes of the fish at the end of the experiment. It was observed that the greatest fillet yield value was found in the treatment in which amounts of $25 \%$, $25 \%, 25 \%$ and $25 \%$ (T1) of the daily feeding were used, with values of $32.57 \pm 1.69 \%$, significantly different from the rest of the treatments $(\mathrm{p}<0.05)$, but was not significantly different from the treatment in which amounts of 20\%, 30\%, 20\% and 30\% (treatment T4) of the daily feeding were used, with values of $30.76 \pm 1.12 \%$ ( $>0.05)$.

Table 5. Fillet (F\%), head (H\%) and carcass (C\%) yields, viscerosomatic (GSI\%), hepatosomatic (HSI\%) and visceral fat-somatic (VFSI\%) indices at the end of the experiment.

\begin{tabular}{lllllll}
\hline Treat. & $\mathrm{F}(\%)$ & $\mathrm{H}(\%)$ & $\mathrm{C}(\%)$ & GSI $(\%)$ & HSI $(\%)$ & VFSI $\left.(\%)^{\mathrm{a}}\right)$ \\
\hline T 1 & $32.56 \pm 1.69^{\mathrm{a}}$ & $17.50 \pm 2.98^{\mathrm{a}}$ & $34.28 \pm 8.15^{\mathrm{a}}$ & $8.61 \pm 2.86^{\mathrm{a}}$ & $1.61 \pm 0.30^{\mathrm{a}}$ & $0.40 \pm 0.03^{\mathrm{a}}$ \\
T 2 & $26.06 \pm 1.50^{\mathrm{b}}$ & $12.54 \pm 3.69^{\mathrm{a}}$ & $29.86 \pm 8.08^{\mathrm{a}}$ & $8.91 \pm 2.52^{\mathrm{a}}$ & $1.18 \pm 0.30^{\mathrm{a}}$ & $0.48 \pm 0.02^{\mathrm{a}}$ \\
T 3 & $27.73 \pm 1.45^{\mathrm{b}}$ & $12.92 \pm 1.82^{\mathrm{a}}$ & $34.78 \pm 2.24^{\mathrm{a}}$ & $7.57 \pm 2.77^{\mathrm{a}}$ & $2.01 \pm 0.16^{\mathrm{a}}$ & $0.65 \pm 0.04^{\mathrm{b}}$ \\
T 4 & $30.76 \pm 1.12^{\mathrm{a}}$ & $11.23 \pm 4.06^{\mathrm{a}}$ & $27.41 \pm 6.78^{\mathrm{a}}$ & $8.38 \pm 2.62^{\mathrm{a}}$ & $1.40 \pm 0.84^{\mathrm{a}}$ & $0.71 \pm 0.03^{\mathrm{b}}$ \\
\hline
\end{tabular}

Values are expressed as averages and standards errors. Equal letters indicate absence of significant differences.

At the end of the experiment, in all treatments, head $(\mathrm{H} \%)$ and carcass $(\mathrm{C} \%)$ fish yields, and viscerosomatic (GSI\%) and hepatosomatic (HSI\%) indices did not show significant differences. However, with relation to the visceral fat-somatic index, the smallest values were obtained in the treatments in which amounts of $25 \%, 25 \%, 25 \%$ and $25 \%$ (T1) and 20\%, 30\%, 30\% and 20\% (T2) of the daily feeding were utilized, with values of $0.40 \pm 0.03$ and $0.48 \pm 0.02 \%$, respectively, significantly different from the rest of the treatments $(p<0.05)$, but not significantly different from each other.

As such, at the end of the experiment, as shown in Table 5, the Nile tilapia, O. niloticus, fed with amounts of 20\%, 30\%, 30\% and $20 \%$ (treatment T4) of the daily quantity presented the greatest values of viscerosomatic fat, also demonstrated by the average final weight, biomass, average final length, and mean daily weight gain of the animals (Table 4).

Michelato et al. (2016) studied lysine exigency in order to improve the muscular development and yield of Nile tilapia ( $O$. niloticus) fillets. 600 fish were used, with an average weight of $274.9 \pm 3.3 \mathrm{~g}$, distributed in fifteen $1.2 \mathrm{~m}^{3}$ cages, with five treatments and three replications, comprising $(11.1 ; 12.5 ; 13.9 ; 15.1$ and $16.4 \mathrm{~g}$ of lysine $\mathrm{kg}^{-1}$ ). The authors verified that the yield of the fillet presented a greater value when the fish were fed with $15.1 \mathrm{~g}$ of lysine $\mathrm{kg}^{-1}(30.69 \pm 0.04 \%)$, with a final weight of $175.13 \pm 1.42 \mathrm{~g}$, in comparison with other treatments.

In the present work, the greatest fillet yield was observed in the treatment in which the fish were fed with amounts of $25 \%, 25 \%, 25 \%$ and $25 \%$ (T1) of the daily feeding, with values of $32.57 \pm 1.69 \%$, presenting a better result in comparison with that verified by the respective authors, using only a commerical ration without lysine supplementation.

Neira et al. (2016) aiming for genetic improvement, evaluated the fillet yield and composition of four bloodlines of Nile tilapia, $O$. niloticus, using individuals that did and did not go through the sex reversal process. The authors verified that the higher values of fillet yield occurred with animals that went through the sex reversal process $(39.10 \pm 2.3 \%)$, with a final weight of $355.0 \pm 110.0 \mathrm{~g}$, much higher than those values observed in our work.

With the substitution of soybean meal (SBM) for sesame meal (SM) in seven different levels $(0 ; 8 ; 16 ; 24 ; 32 ; 40$ and $48 \%$ of SM for $\mathrm{SBM})$ in a diet for Nile tilapia (O. niloticus) fry, with an initial average weight of $8.74 \pm 0.12 \mathrm{~g}$ during a period of 8 weeks, Guo et al. (2011) did not verify significant differences between the substitutions and the control treatment in relation to the viscerosomatic and hepatosomatic indices of the fish in the tested treatments. 
Performance of the...

However, Navarro et al. (2010) observed significant differences with regard to the viscerosomatic index of reversed post-larval tilapia upon the supplementation of isoproteic (36\% of PB) and isocaloric $\left(3600 \mathrm{kcal}\right.$ of $\left.\mathrm{ED} . \mathrm{kg}^{-1}\right)$ ration in the concentrations of $0 ; 50 ; 100$ and $150 \mathrm{mg}$. kg-1 of monophasic vitamin $\mathrm{E}$ during a period of 106 days.

Huang et al. (2015) evaluated the effect of zinc in semi-purified diets of adult Nile tilapia $(O$. niloticus) and its effects on growth, mineral tissue composition and antioxidant responses. The authors provided concentrations of zinc in totals of 15.9; $28.0 ; 36.4 ; 53.5 ; 99.7 ; 176.7$ and $334.0{\mathrm{mg} . ~ \mathrm{~kg}^{-1}}$ in the diet, in three duplicate groups of 15 tilapia, with an initial weight of $166.9 \pm 1.3 \mathrm{~g}$ during 12 weeks. The weight gain of the animals increased with an elevation of the concentration of zinc in the diet (from 15.9 to $53.5 \mathrm{mg}$. kg-1), and subsequently decreased beyond these levels. The zinc content in the liver, muscles, and bones showed a similar tendency. The iron and magnesium content in the liver, muscles, and bones were significantly affected by the levels of zinc in the diet.

Mahfouz and Sherif (2015) investigated the adverse effects of aflatoxin B1 (AFB1) toxicity on the growth, survival rate, and hepatosomatic index
ARAUJO, G. S. et al.

(HSI) of Nile tilapia, O. niloticus. The fish were fed with a diet contaminated with 20 or $100 \mathrm{ppb}$ of AFB1 for 6 or 12 weeks and the authors verified, in a diet containing $100 \mathrm{ppb}$ of AFB1, a negative impact on weight gain, feed conversion, hematological profiles, the hepatosomatic index, as well as on their hepatic histopathology, showing that the observed alterations in the state of fish health, especially in the liver, are related to the oxidative stress due to aflatoxin toxicity.

In our work, the lowest values on the hepatosomatic index were observed in treatment $\mathrm{T} 2$, in which amounts of $20 \%, 30 \%, 30 \%$ and $20 \%$ of the daily feeding were used, but did not differ from the rest of the treatments $(\mathrm{p}>0.05)$ (Table 5).

\section{Elementary chemical analysis}

Finally, the average values of moisture, crude protein, lipid and ash presented in fillet composition in this work was to evaluate the influence of different feed amounts offered throughout the day on the growth performance of Nile tilapia (Oreochromis niloticus) were similar in all treatments, without significant difference between them (Table 6).

Table 6. Moisture, crude protein, lipid and ash average values in Nile tilapia (Oreochromis niloticus) fillet compositions in all treatments.

\begin{tabular}{llllll}
\hline Composition (\%) & \multicolumn{3}{c}{ Treatments } & CV \\
\cline { 2 - 5 } & T1 & T2 & T3 & T4 & \\
\hline Moisture & $78.55^{\mathrm{a}}$ & $78.80^{\mathrm{a}}$ & $78.75^{\mathrm{a}}$ & $78.43^{\mathrm{a}}$ & 0.31 \\
Crude protein & $17.45^{\mathrm{a}}$ & $17.21^{\mathrm{a}}$ & $17.43^{\mathrm{a}}$ & $17.33^{\mathrm{a}}$ & 1.38 \\
Lipid & $1.07^{\mathrm{a}}$ & $1.13^{\mathrm{a}}$ & $0.98^{\mathrm{a}}$ & $1.15^{\mathrm{a}}$ & 4.02 \\
Ash & $1.34^{\mathrm{a}}$ & $1.28^{\mathrm{a}}$ & $1.35^{\mathrm{a}}$ & $1.35^{\mathrm{a}}$ & 4.52 \\
\hline
\end{tabular}

Equal letters indicate absence of significant differences between treatments. CV is the coefficient of variation.

The yield and bromatological composition of fillet were better in tilapia submitted to two and to four meals daily than in smaller frequencies, such as a meal in each two days or a meal per day (PÁDUA, 2001).

Reda et al. (2016) evaluated the use of a mixture of formic acid, propionic acid, and calcium propionate and its salts in comparison with oxytetracycline, in apparently healthy Nile tilapia (O. niloticus) fry, with an average weight of $28.8 \pm 0.14 \mathrm{~g}$, for a period of 60 days. The authors observed that the fish fed with the diet containing formic acid and a mixture of propionic acid/salt in 2 g. $\mathrm{kg}^{-1}$ presented elevated protein content and body fat when compared with other treatments.

In our work, the highest protein indices were observed in treatment $\mathrm{T} 1$, in which amounts of $5 \%, 25 \%, 25 \%$ and $25 \%$ of the daily feeding were used, but did not differ from the rest of the treatments $(p>0.05)$. Meanwhile, the lipid content was higher in treatment $\mathrm{T} 4$, in which amounts of $20 \%, 30 \%, 20 \%$ and $30 \%$ of the daily feeding were used, but this also did not differ from the rest of the treatments $(p>0.05)$ (Table 6).

Michelato et al. (2016) studied lysine exigency for the improvement of muscular development and fillet yield of Nile tilapia, $O$. niloticus, with an average weight of $274.9 \pm 3.3 \mathrm{~g}$, distributed in fifteen $1.2 \mathrm{~m}^{3}$ cages, with five treatments and three replications. The authors verified that the highest values of moisture occurred in the treatment in which $12.5 \mathrm{~g}$ of lysine $\mathrm{kg}^{-1}$ $(78.48 \pm 0.45 \%)$ was used; with regards to protein, the best results occurred in the treatment which included $11.1 \mathrm{~g}$ of lysine $\mathrm{kg}^{-1}(17.14 \pm 0.15 \%)$ and lipids, and the treatment with utilization of $13.9 \mathrm{~g}$ of 
lysine $\mathrm{kg}^{-1}(3.97 \pm 0.23 \%)$ and ash, with the best result occurring in the treatment including $11.1 \mathrm{~g}$ of lysine $\mathrm{kg}^{-1}(1.10 \pm 0.02 \%)$.

In general, the values found in the present work are similar to those verified by authors with regards to the moisture and ash content, however the protein yield deserves to be pointed out, which in our work was higher in all of the studied treatments, in addition to the results regarding lipid content, which was less, observed in all the treatments (Table 6).

Koch et al. (2016) evaluated the feeding of Nile tilapia, $O$. niloticus, with an average weight of $6.81 \mathrm{~g}$, utilizing commercial diets free of fishmeal. The authors verified that higher values of moisture occurred in the treatment which utilized $11.2 \%$ poultry meal and $44.5 \%$ soymeal $(73.67 \%)$; with respect to protein, the best result occurred in the treatment utilizing $15.1 \%$ poultry meal and $39.2 \%$ soymeal (11.76 and $2.55 \%$, respectively).

In general, the values found in the respective work are higher than those verified by the author with respect to protein, and lower with respect to ash content (Table 6).

\section{CONCLUSION}

Greatest biomass, final average weight and best feed conversion were obtained when the tilapia were fed in the daily amounts of 20 and $30 \%$ of the total daily offered ration.

RESUMO: Para avaliar o desempenho da tilápia do Nilo (Oreochromis niloticus), as quantidades diárias de alimentação foram variadas em um experimento após um delineamento inteiramente casualizado de 154 dias e consistindo em quatro tratamentos com três repetições cada, totalizando 12 tanques com 3 m3 (3 x 1 x $1 \mathrm{~m}$ ) de área cada uma em densidades de 5 peixes m-3 (inicial) e 3 peixes $\mathrm{m}-3$ até o final do experimento. Ao longo do período experimental, a quantidade diária de alimentos foi variada e delimitada para cada tempo de alimentação (8h00, 11h00, 14h00 e 17h00) como: 25; 25; 25 e 25\% no tratamento diário 1 - T1; 20; $30 ; 30$ e $20 \%$ no tratamento 2 - T2; 30; 20; 20 e 30\% no tratamento diário 3 - T3; e 20; 30; 20 e $30 \%$ no tratamento 4 T4. O alimento foi oferecido seis dias por semana, com dietas isocalóricas extrudadas (1.412 KJ) e isoprotéicas (32\% de proteínas brutas) de 2 a $4 \mathrm{~mm}$. A cada duas semanas, uma amostra contendo 30\% de indivíduos estocados foi coletada em cada replicação para monitorar o crescimento do peixe. Tilápias do Nilo $(O$. niloticus) alimentadas em quantidades diárias de 20; 30; 20 e 30\% mostraram um melhor desempenho de crescimento no final do experimento, principalmente na biomassa, peso médio final e conversão alimentar.

PALAVRAS-CHAVE: Aquicultura. Cultivo. Crescimento. Oreochromis niloticus. Produção.

\section{REFERENCES}

ALI, M.; NICIEZA, A.; WOOTTON, R. J. Compensatory growth in fishes: a response to growth depression. Fish and Fisheries, Oxford, v. 4, p. 147-190, 2003. https://doi.org/10.1046/j.1467-2979.2003.00120.x

ARAUJO, G. S.; RODRIGUES, J. A. G.; DA SILVA, J. W. A.; FARIAS, W. R. L. Cultivo da tilápia do Nilo em tanques-rede circulares em diferentes densidades de estocagem. Bioscience Journal, Uberlândia, v. 26, n. 3, p. 428-434, 2010.

ASSOCIATION OF OFFICIAL ANALYTICAL CHEMISTRY - AOAC. Official methods of analysis. 16 th ed. Washington: DC, USA, 1995.

CARNEIRO, P. C. F.; CYRINO, J. E. P; CASTAGNOLLI, N. Produção da tilápia vermelha da Flórida em tanques-rede. Scientia Agricola, Piracicaba, v. 56, n. 3, p. 673-679, 1999. https://doi.org/10.1590/S010390161999000300023

CARNEIRO, P. C. F.; MIKOS, J. D. Frequência alimentar e crescimento de alevinos de jundiá, Rhamdia quelen. Ciência Rural, Santa Maria, v. 35, n. 1, p. 187-191, 2005. https://doi.org/10.1590/S010384782005000100030 
CRUZ, E. M. V.; MAIR, G. C. Conditions for effective androgen sex reversal in Oreochromius niloticus (L). Aquaculture, Amsterdam, v. 122, n. 2-3, p. 237-248, 1994. https://doi.org/10.1016/0044-8486(94)90513-4

FOOD AND AGRICULTURE ORGANIZATION OF THE UNITED NATIONS - FAO. The definition of aquaculture and collection of statistics. Aquaculture Minutes, Rome, n. 7, 1990.

FREATO, T. A.; DE FREITAS, R. T. F.; PIMENTA, M. E. D. G.; DE OLIVEIRA, G. R.; NETO, R. V. R.; DE MATOS, B. O. Evaluation of Nile tilapia strains cultivated in cages under different feeding programmers.

Brazilian Journal of Animal Science, Viçosa, v. 41, n. 6, p. 1332-1336, 2012. https://doi.org/10.1590/S151635982012000600002

GONÇALVES, A. F. N.; HA, N.; BILLER-TAKAHASHI, J. D.; SATO, L. S.; KISHIMOTO, M. K.; TAKAHASHI, L. S. Densidade de estocagem e restrição alimentar em juvenis de piapara. Boletim do Instituto de Pesca, São Paulo, v. 40, n. 3, p. 431-439, 2014.

GUERRERO, R. D. Use of androgens for production of all-male Tilapia aurea (Steindachner). Journal Transactions of the American Fisheries Society, v. 104, n. 2, p. 342-348, 1975. https://doi.org/10.1577/1548-8659(1975)104<342:UOAFTP>2.0.CO;2

GUO, Y.; DONG, X.; TAN, B.; CHI, S.; YANG, Q.; CHEN, G.; ZHANG, L. Partial replacement of soybean meal by sesame meal in diets of juvenile Nile tilapia, Oreochromis niloticus L. Aquaculture Research, Medford, v. 42, p. 1298-1307, 2011. https://doi.org/10.1111/j.1365-2109.2010.02718.x

GURNEY, W. S. C.; JONES, W.; VEITCH, A. T.; NISBET, R. M. Resource allocation, hyperphagia, and compensatory growth in juveniles. Ecology, Washington, v. 84, p. 2777-2787, 2003.

https://doi.org/10.1890/02-0536

HUANG, F.; JIANG, M.; WEN, H.; WU, F.; LIU, W.; TIAN, J.; YANG, C. Dietary zinc requirement of adult Nile tilapia (Oreochromis niloticus) fed semi-purified diets, and effects on tissue mineral composition and antioxidant responses. Aquaculture, Amsterdam, v. 439, p. 53-59, 2015.

https://doi.org/10.1016/j.aquaculture.2015.01.018

KOCH, J. F.; RAWLES, S. D.; WEBSTER, C. D.; CUMMINS, V.; KOBAYASHI, Y.; THOMPSON, K. R.; GANNAM, A. L.; TWIBELL, R. G.; HYDE, N. M. Optimizing fish meal-free commercial diets for Nile tilapia, Oreochromis niloticus. Aquaculture, Amsterdam, v. 452, p. 357-366, 2016.

https://doi.org/10.1016/j.aquaculture.2015.11.017

LIMA, C. B.; DE OLIVEIRA, E. G.; DE ARAÚJO, J. M.; SANTOS, F. J. D.; PEREIRA, W. E. Water quality in irrigation channels stoked with nile tilapia (Oreochromis niloticus). Revista Ciência Agronômica,

Fortaleza, v. 39, n. 4, p. 531-539, 2008.

LOURES, B. T. R. R.; RIBEIRO, R. P.; VARGAS, L.; MOREIRA, H. L. M.; SUSSEL, F. R.; POVH, J. A.; CAVICHIOLO, F. Manejo alimentar de alevinos de tilápia do Nilo, Oreochromis niloticus (L.), associado às variáveis físicas, químicas e biológicas do ambiente. Acta Scientiarum, Maringá, v. 23, n. 4, p. 877-883, 2001. https://doi.org/10.4025/actascianimsci.v23i0.2640

MAHFOUZ, M. E.; SHERIF, A. H. A multiparameter investigation into adverse effects of aflatoxin on Oreochromis niloticus health status. The Journal of Basic \& Applied Zoology, London, v. 71, p. 48-59, 2015. https://doi.org/10.1016/j.jobaz.2015.04.008

MARTINEZ-CORDOVA, L. R.; PORCHAS-CORNEJO, M. A.; VILLARREAL-COLEMNARES, H.; CALDERON-PEREZ, J. A.; NARANJO-PARAMO, J. Evaluation of three feeding strategies on the culture of white shrimp Penaeus vannamei Boone 1931 in low water exchange ponds. Aquaculture Engineering, Oxford, v. 17, p. 21-28, 1998. https://doi.org/10.1016/S0144-8609(97)00010-1 
MEURER, F.; HAYASHI, C.; SOARES, C. M.; BOSCOLO, W. R. Utilização de levedura spray dried na alimentação de alevinos de tilápia do Nilo (Oreochromis niloticus L.). Acta Scientiarum, Maringá, v. 22, n. 2, p. $479-484,2000$.

MEURER, F.; HAYASHI, C.; BOSCOLO, W. R.; KAVATA, L. B.; LACERDA, C. H. F. Nível de arraçoamento para alevinos de lambari-dorabo-amarelo (Astyanax bimaculatus). Revista Brasileira de Zootecnia, Viçosa, v. 34, n. 6, p. 1835-1840, 2005. https://doi.org/10.1590/S1516-35982005000600006

MEURER, F.; SILVA, M. S.; COLPINI, L. M. S.; FRECCIA, A.; MAUERWERK, L. Nível de arraçoamento de pós-larvas de tilápia do Nilo em baixa temperatura. Revista Científica de Produção Animal, Areia, v. 9, n. 1, p. 76-83, 2007.

MICHELATO, M.; VIDAL, L. V. O.; XAVIER, T. O.; MOURA, L. B.; DE ALMEIDA, F.L.A.; PEDROSA, V. B.; FURUYA, V. R. B.; FURUYA, W. M. Dietary lysine requirement to enhance muscle development and fillet yield of finishing Nile tilapia. Aquaculture, Amsterdam, v. 457, p. 124-130, 2016.

https://doi.org/10.1016/j.aquaculture.2016.02.022

MOREIRA, R. L.; DA COSTA, J. M.; DE MOURA, P. S.; FARIAS, W. R. L. Salinidade da água e suplementação alimentar com microalga marinha no crescimento e masculinização de Oreochromis niloticus, tilápia do Nilo, Bioscience Journal, Uberlândia, v. 27, n. 1, p. 116-124, 2011.

NAVARRO, R. D.; FERREIRA, W. M.; RIBEIRO FILHO, O. P.; VELOSO, D. P.; FONTES, D. O.; SILVA, R. F. Desempenho de tilápia do Nilo (Oreochromis niloticus) suplementada com vitamina E. Archivos de Zootecnia, Córdoba, v. 59, n. 226, p. 185-194, 2010. https://doi.org/10.21071/az.v59i226.4733

NEIRA, R.; GARCÍA, X.; LHORENTE, J. P.; FILP, M.; YÁÑEZ, J. M.; CASCANTE, A. M. Evaluation of the growth and carcass quality of diallel crosses of four strains of Nile tilapia (Oreochromis niloticus).

Aquaculture, Amsterdam, v. 451, p. 213-222, 2016. https://doi.org/10.1016/j.aquaculture.2015.08.033

NG, W. K.; WANG, Y. Inclusion of crude palm oil in the broodstock diets of female Nile tilapia, Oreochromis niloticus, resulted in enhanced reproductive performance compared to broodfish fed diets with added fish oil or linseed oil. Aquaculture, Amsterdam, v. 314, p. 122-131, 2011.

https://doi.org/10.1016/j.aquaculture.2011.01.034

OSTRENSKY, Antônio; BORGHETTI, José Roberto; SOTO, Doris. Aquicultura no Brasil: o desafio é crescer. Brasília: Distrito Federal, 2008. 276 p.

PÁDUA, D. M. C. A frequência alimentar e a utilização dos nutrientes da dieta pela Tilápia do Nilo, Oreochromis niloticus. 2001. 103 f. Tese (Doutorado em Zootecnia) - Centro de Aquicultura da Universidade Estadual Paulista - CAUNESP, Jaboticabal, 2001.

PHELPS, R. P.; SALAZAR, G. C.; ABE, V.; ARGUE, B. J. Sex reversal and nursery growth of Nile tilapia (L), free-swimming in earth ponds. Aquaculture Research, Medford, v. 26, n. 4, p. 293-295, 1995. https://doi.org/10.1111/j.1365-2109.1995.tb00915.x

POPMA, T. J.; GREEN, B. W. Sex reversal of tilapia in earthen ponds. Research and Development Series. No. 5. Alabama Agricultural Experiment Station: Auburn University, Alabama, USA, 1990. 15 p.

REDA, R. M.; MAHMOUD, R.; SELIM, K. M.; EL-ARABY, I. E. Effects of dietary acidifiers on growth, hematology, immune response and disease resistance of Nile tilapia, Oreochromis niloticus. Fish \& Shellfish Immunology, London, v. 50, p. 255-262, 2016. https://doi.org/10.1016/j.fsi.2016.01.040

SALARO, A. L.; LUZ, R. K.; SAKABE, R.; KASAI, R. Y. D.; LAMBERTUCCI, D. M. Níveis de arraçoamento para juvenis de trairão (Hoplias lacerdae). Revista Brasileira de Zootecnia, Viçosa, v. 37, n. 6, p. 967-970, 2008. https://doi.org/10.1590/S1516-35982008000600002 
SAMPAIO, J. M. C.; BRAGA, L. G. T. Cultivo de tilápia em tanques-rede na barragem do Ribeirão de Saloméa - Floresta Azul - Bahia. Revista Brasileira de Saúde e Produção Animal, Salvador, v. 6, n. 2, p. 42 $52,2005$.

SANCHES, L. E. F.; HAYASHI, C. Effect of feeding frequency on Nile tilapia, Oreochromis niloticus (L.) fries performance during sex reversal in hapas. Acta Scientiarum, Maringá, v. 23, n. 4, p. 871-876, 2001.

SANTOS, J. A.; AZEVEDO, F. V. S. T. M.; ALVES, I. T. F.; SILVA, G. P. Influência das densidades de estocagem na qualidade da água e no desempenho produtivo de alevinos de tilápia (Oreochomis niloticus) cultivados em tanques-rede. Enciclopédia Biosfera, Goiânia, v. 9, n. 16, p. 170-177, 2013.

SANTOS, L. E.; SANTOS, F. V. V. I.; LIRA, C. R.; SILVA, F. C.; MOURA, S. C. S; FERREIRA, S. J. A.; SILVA, M. R. Frequência de arraçoamento para alevinos de tilápias do Nilo (Oreochromis niloticus).

Agropecuária Técnica, Areia, v. 35, n. 1, p.171-177, 2014.

SANTOS, M. M.; CALUMBY, J. A.; COELHO FILHO, P. A.; SOARES, E. C.; GENTELINI, A. L. Nível de arraçoamento e frequência alimentar no desempenho de alevinos de tilápia do Nilo. Boletim do Instituto de Pesca, São Paulo, v. 41, n. 2, p. 387-395, 2015.

SEYMOUR, E. A. Devising optimum feeding regimes and temperatures for warmwater cuture of eel, Anguilla anguilla L. Aquaculture Research, Medford, v. 20, n. 3, p. 311-323, 1989. https://doi.org/10.1111/j.13652109.1989.tb00356.x

SOARES, E. C.; PEREIRA-FILHO, M.; ROUBACH, R.; SOARES, R. C. Condicionamento alimentar no desempenho zootécnico do tucunaré. Revista Brasileira de Engenharia de Pesca, São Luís, v. 2, p. 35-48, 2007.

SOUZA, V. L.; URBINATI, E. C.; OLIVEIRA, E. G. Restrição alimentar, realimentação e as alterações no desenvolvimento de juvenis de pacu (Piaractus mesopotamicus, HOLMBERG, 1887). Boletim do Instituto de Pesca, São Paulo, v. 24, p. 19-24, 1997.

TRAN-DUY, A.; SCHRAMA, J. W.; VAN DAM, A. A; VERRET, J. A. J. Effects of oxygen concentration and body weight on maximum feed intake, growth and hematological parameters of Nile tilapia, Oreochromis niloticus. Aquaculture, Amsterdam, v. 275, n. 1-4, p. 152-162, 2008.

https://doi.org/10.1016/j.aquaculture.2007.12.024

WATANABE, W. O.; LOSORDO, T. M.; FITZSIMMONS, K.; HANLEZ, F. Tilapia production systems in the Americas: technological advances, trends and challenges. Reviews in Fisheries Science, Bethesda, v. 10, n. 34, p. 465-498, 2002. https://doi.org/10.1080/20026491051758

YAO, S. J.; UMINO, T.; NAKAGAWA, H. Effect of feeding frequency on lipid accumulation in ayu. Fisheries Science, Tokyo, v. 60, p. 667-671, 1994. https://doi.org/10.2331/fishsci.60.667 